\title{
INAKTIVASI ENZIM PROTEASE PADA PUREE EDAMAME (Glycine max) MENGGUNAKAN TEKNIK PULSED ELECTRIC FIELD (PEF)
}

Inactivation of Edamame (Glycine max) Puree's Protease Using Pulsed Electric Field (PEF) Technique

\author{
Mila Damanik Ariyantini ${ }^{1)}$, Mukhammad Fauzi ${ }^{1)}$, Jayus Jayus ${ }^{1) *}$ \\ ${ }^{1)}$ Jurusan Teknologi Hasil Pertanian, Fakultas Teknologi Pertanian, Universitas Jember \\ Jalan Kalimantan 37, Kampus Tegal Boto Jember 68121 \\ *E-mail: jayus.ftp@unej.ac.id
}

\begin{abstract}
Edamame (Glycine max) is easily damaged due to suspected enzyme content and microbial activity, so the ingredients must be consumed directly after blanching process. Selling value of rejected edamame is very low while the nutritional content is still quite good. To increase the edamame selling value, an alternative processing is needed which could maintain the edamame shelf life. The alternative way was creating edamame puree which had a longer shelf life without damaging the characteristics of edamame puree. Preservation of edamame puree was done by enzyme inactivation using Pulsed Electric Field (PEF) method. The results showed that PEF treatment could inactivate protease enzyme up to $88,5 \%$, microbe $80-89 \%$, antioxidant activity $44,5 \%$ and color $2,43 \%$. The activity of edamame protease enzymewas significantly decreased at $45 \mathrm{kV}$ voltage treatment; 30 seconds $(0.38$ $\mathrm{mMol} / \mathrm{minutes}$ ). Total microbial in puree edamame significantly decreased at $40 \mathrm{kV}$ voltage treatment; 10 second $(2,849 \log \mathrm{Cfu} / \mathrm{ml})$ and $40 \mathrm{kV}$ voltage control; 20 second; $40 \mathrm{kV} ; 30$ second; $45 \mathrm{kV}$; 10 second; $45 \mathrm{kV}$; 20 second; And $45 \mathrm{kV}$; 30 second (not growing). Antioxidant activityof edamame puree after PEF treatment was significantly decreased at 45 $k V ; 30$ seconds (5.43\%). In addition, treatment of PEF also maintains the hue angle puree edamame color remains in a yellowish greenish marked by a fixed value of susceptible 126 162. The value of hue angle edamame puree before and after PEF treatment ranged from $153.76-150.02$.
\end{abstract}

Keywords: edamame, puree edamame, protease enzyme, PEF technique

\section{PENDAHULUAN}

Edamame merupakan kedelai jenis sayur (soybean vegetable) yang termasuk spesies Glycine max dan memiliki produktivitas tinggi dimana satu hektar bisa menghasilkan $\pm 10-12$ ton. Hal ini jauh lebih tinggi diatas rata-rata jenis kedelai lainnya yang berkisar 1,5 ton -3 ton per hektar (Setkab, 2014). Khusus Kabupaten Jember, produksi kedelai edamame tahun 2013 tercatat 27.732 ton dengan kebutuhan konsumsi 25.473 ton sehingga mengalami surplus 2.259 ton (Setkab, 2014).
Edamame memiliki nilai gizi yang cukup tinggi yakni $582 \mathrm{Kkal}$, protein 11,4 g; karbohidrat 7,4 g; lemak 6,6 g; vitamin A $100 \mathrm{mg}$; B1 0,27 mg; B2 0,14 mg; B3 1 mg; dan vitamin C 27\%; serta mineralmineral seperti fosfor $140 \mathrm{mg}$; kalsium 70 $\mathrm{mg}$; besi $1,7 \mathrm{mg}$; dan kalium $140 \mathrm{mg}$ dalam $100 \mathrm{~g}$ edamame (Johnson, et al. 1999, Nguyen, 2001) dan mengandung sembilan asam amino esensial yang diperlukan tubuh, tidak mengandung kolesterol dan sedikit lemak jenuh serta kaya serat, vitamin $\mathrm{C}$ dan $\mathrm{B}$, kalsium, zat besi atau magnesium, dan asam folat (Setkab, 2014). 
Pada umumnya edamame dikonsumsi secara langsung setelah proses blanching, karena edamame memiliki umur simpan yang rendah. Oleh karena itu, perlu adanya diversifikasi edamame menjadi puree (bubur buah) yang merupakan produk setengah jadi dari edamame sebagai bahan baku pembuatan sari edamame atau nektar, produk roti, susu, permen, selai dan jeli (Broto, 2003). Puree edamame memiliki sifat perishable, sehingga memiliki umur simpan yang rendah. Hal ini dapat diakibatkan karena adanya reaksi enzim yang terkandung di dalam puree edamame secara berlebihan, selain kontaminasi mikroba.

Enzim yang terkandung dalam edamane diantaranya urease, lipoksigenase, peroksidase dan protease yang berpotensi merusak dan mengurangi mutu dari hasil olahan edamame.Secara umum proses pengawetan melibatkan perlakuan panas karena sangat efektif dalam mempertahankan kualitas umur simpan. Kelemahan proses pemanasan pada pengawetan puree edamame akan berakibat pada penurunan kandungan nutrisi edamame, terutama komponenkomponen yang tidak tahan panas.

PEF merupakan salah satu teknik pengolahan pangan non-termal dengan menggunakan kejutan listrik intensitas tinggi yang diaplikasikan pada bahan pangan berbentuk cair dengan tujuan untuk memperkecil kerusakan yang disebabkan oleh pemanasan. Keuntungan dari teknik ini yaitu dapat mempertahankan warna, tekstur, dan aroma original serta nilai nutrisi pada saat proses pengawetan (Quass, 1997).

\section{METODE PENELITIAN}

Alat dan Bahan

Alat-alat yang digunakan untuk pembuatan puree edamame meliputi rangkaian alat Pulsed Electric Field (PEF) dan blender (Philips). Glassware (Pyrex), magnetic stirrer (Medline MS3OOHS, Jerman), Penangas (Medline MS3OOHS,
Jerman), shaker water bath (Model Orbital Shaking Incubator), neraca analitik (ES 2200C dan ES 225SM-DR, Swiss), pH meter (F-51), mikropipet, spektrofotometer (Spectrophotometer model U-2900UV type VIS 2JI-0004, Jepang), colour reader (CR-10 Minolta), lemari pendingin (Sharp), sentrifuse (Centrifudge Floor Standing type CR21GIII, Jepang) dan tabung setrifuse.

Bahan yang digunakan dalam pembuatan puree edamame adalah polong kedelai edamame berasal dari PT. Mitra Tani 27 Kabupaten Jember, etanol 90\%; 1 $\mathrm{M}$ buffer fosfat $\mathrm{pH} 7 \quad\left(\mathrm{KH}_{2} \mathrm{PO}_{4}\right.$ dan $\left.\mathrm{K}_{2} \mathrm{HPO}_{4}\right) ; 0,6 \%$ larutan kasein; 0,4 M tricholoroacetic acid (TCA); 0,4 M sodium karbonat $\left(\mathrm{Na}_{2} \mathrm{CO}_{3}\right)$; dan $0,67 \mathrm{~N}$ Folin ciocalteau, reagen DPPH, etanol $96 \%$.

\section{Tahapan Penelitian}

\section{Pembuatan Puree Edamame}

Kedelai edamame dikupas kulitnya, kemudian dilakukan pembersihan polong dari kulit ari yang tersisa. Langkah selanjutnya adalah proses blansing selama 3 menit menggunakan suhu $82^{\circ} \mathrm{C}$. Selanjutnya adalah perendaman dengan air es selama 10 detik kemudian dilakukan penghalusan selama 8 menit.

\section{Rancangan Percobaan}

Penelitian ini menggunakan 2 faktor. Faktor I terdiri dari 3 level dan faktor II terdiri dari 3 level. Faktor I merupakan variasi tegangan (A) yaitu $35 \mathrm{kV}, 40 \mathrm{kV}$, dan $45 \mathrm{kV}$ terhadap $100 \mathrm{ml}$ larutan. Faktor kedua merupakan variasi waktu (B) yang terdiri dari 3 level yaitu 10 detik, 20 detik, dan 30 detik.

\section{Metode Analisis}

Uji yang dilakukan pada puree edamame meliputi aktivitas enzim protease (Oh et al., 2016), total pertumbuhan mikroba (Arisusanti, 2010), aktivitas antioksidan (Nooman et al. 2008), hue angle (Hutching, 1999); sifat 
organoleptik (Meilgard, 1999), dan pengamatan umur simpan.

\section{HASIL DAN PEMBAHASAN}

\section{Aktivitas Enzim Protease}

Bahan pangan pada dasarnya mengandung enzim yang disebut dengan enzim endogenous, salah satu enzim yang terkandung dalam bahan pangan adalah enzim protease. Setelah mengalami pasca panen enzim tersebut masih aktif dan bermetabolisme. Proses ini tidak diinginkan karena dapat mengurangi mutu suatu produk (Chandrasekran, 2016). Aktivitas tertinggi yaitu pada perlakuan kontrol 16,49 $\mathrm{mMol} /$ menit dan terendah pada perlakuan $\mathrm{A}_{3} \mathrm{~B}_{3} 1,89 \mathrm{mMol} /$ menit. Aktivitas enzim protease pada puree edamame dapat dilihat pada Gambar 1.

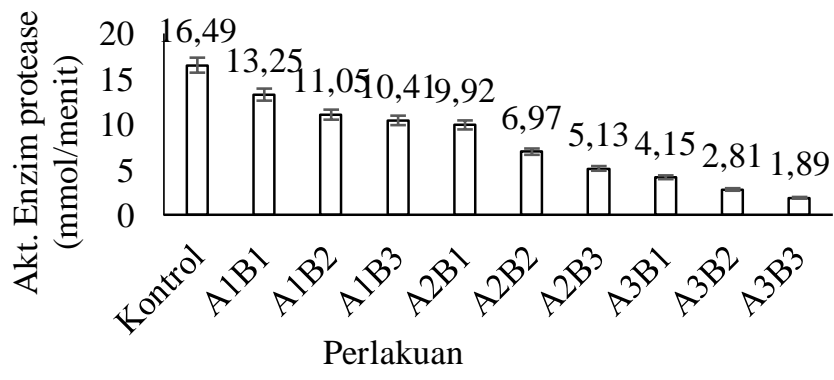

Gambar1.Aktivitas enzim proteasepuree edamame dengan variasi tegangan dan waktu PEF

Gambar 1 menunjukkan inaktivasi enzim protease ini disebabkan karena adanya peningkatan aktivitas metabolisme yang terlalu tinggi sehingga menggangu kerja dan fungsi fisiologis enzim. Penurunan aktivitas akibat kejutan listrik tegangan tinggi diduga dipengaruhi oleh kerusakan struktur sel, seperti rusaknya membran sitoplasma sel. Meskipun secara alamiah membran sitoplasma mampu disintesa kembali tetapi dengan tegangan tinggi, kerusakan berbentuk lubang pada membran luar dari sel tidak mampu diperbaiki lagi, sehingga memungkinkan terjadinya mobilisasi senyawa makromolekul dari sel yang menyebabkan kehilangan aktivitas (Alberts et al., 1994). Proses kejutan listrik diduga menyebabkan terjadinya ionisasi beberapa garam-garam seperti $\mathrm{Mg}^{2+}$ dan $\mathrm{Ca}^{2+}$ yang terikat pada dinding sel ataupun yang membentuk bufer phosphat dimana tingkat sensitivitas terhadap kejutan listrik lebih besarmenurut Speer (1998).

\section{Total Pertumbuhan Mikroba}

Pertumbuhan bakteri patogen di dalam bahan makanan merupakan hal yang perlu diperhatikan sebab beberapa bakteri patogen mempunyai kaitan erat dengan keracunan makanan. Bakteri ini kerap dijumpai dan dapat bertahan selama proses pengolahan. Hasil dari penelitian mengenai pertumbuhan mikroba pada puree edamame dalam media PCA dapat dilihat pada Tabel 1.

Tabel 1 menunjukkan jumlah total mikroba tertinggi yaitu pada perlakuan kontrol $(3,447 \log \mathrm{Cfu} / \mathrm{ml})$ dan terendah pada perlakuan $\mathrm{A}_{2} \mathrm{~B}_{1}(2,849 \log \mathrm{Cfu} / \mathrm{ml})$, sedangkan pada perlakuan $\mathrm{A}_{2} \mathrm{~B}_{2}$ hingga $\mathrm{A}_{3} \mathrm{~B}_{3}$ tidak menunjukkan adanya pertumbuhan. Inaktivasi mikroba yang dilakukan dengan PEF berhubungan dengan ketidakstabilan membran sel secara elektro-mekanik. Membran sel melindungi mikroba dari kondisi lingkungan sekitar dengan cara bekerja sebagai dinding semipermeable, jika membran sel mengalami pemecahan, maka terjadi pengeluaran cairan dari dalam sel dan kehilangan aktivitas metabolisme sel. Ada dua teori yang menjelaskan tentang proses pemecahan membran sel yaitu dielectric rupture dan electroporation (Sale and Hamilton, 1968 dalam Jeyamkon et al., 2008).

Pengaliran listrik dengan media yang kaya akan nutrisi atau protein menyebabkan terjadinya penurunan nilai efektivitas kematian dari mikroba yang terkandung yang ditandai dengan terjadinya koagulasi protein pada elektroda dengan semakin lama kejutan listrik. Semakin tinggi tingkat koagulasi akan 
sebanding dengan tingkat kematian dari mikroba (Gould et al., 1995).

Tabel 1. Total Pertumbuhan Mikroba

\begin{tabular}{cc}
\hline Perlakuan & $\begin{array}{c}\text { Jumlah Mikroba (log } \\
\text { Cfu/ml) }\end{array}$ \\
\hline Kontrol & 3,447 \\
$\mathrm{~A}_{1} \mathrm{~B}_{1}$ & 3,094 \\
$\mathrm{~A}_{1} \mathrm{~B}_{2}$ & 2,931 \\
$\mathrm{~A}_{1} \mathrm{~B}_{3}$ & 2,931 \\
$\mathrm{~A}_{2} \mathrm{~B}_{1}$ & 2,849 \\
$\mathrm{~A}_{2} \mathrm{~B}_{2}$ & Tidak tumbuh \\
$\mathrm{A}_{2} \mathrm{~B}_{3}$ & Tidak tumbuh \\
$\mathrm{A}_{3} \mathrm{~B}_{1}$ & Tidak tumbuh \\
$\mathrm{A}_{3} \mathrm{~B}_{2}$ & Tidak tumbuh \\
$\mathrm{A}_{3} \mathrm{~B}_{3}$ & Tidak tumbuh \\
\hline
\end{tabular}

Keterangan : Kontol tanpa menggunakan perlakuan PEF; $\mathrm{A}_{1} \mathrm{~B}_{1}=35 \mathrm{kV} ; 10$ detik; $\mathrm{A}_{1} \mathrm{~B}_{2}=35 \mathrm{kV} ; 20$ detik; $\mathrm{A}_{1} \mathrm{~B}_{3}=35 \mathrm{kV} ; 30$ detik; $\mathrm{A}_{2} \mathrm{~B}_{1}=40$ $\mathrm{kV} ; 10$ detik; $\mathrm{A}_{2} \mathrm{~B}_{2}=40 \mathrm{kV} ; 20$ detik; $\mathrm{A}_{2} \mathrm{~B}_{3}$ $=40 \mathrm{kV} ; 30$ detik; $\mathrm{A}_{3} \mathrm{~B}_{1}=45 \mathrm{kV} ; 10$ detik; $\mathrm{A}_{3} \mathrm{~B}_{2}=45 \mathrm{kV} ; 20$ detik; $\mathrm{A}_{1} \mathrm{~B}_{2}=45 \mathrm{kV} ; 30$ detik.

\section{Aktivitas Antioksidan}

Aktivitas antioksidan merupakan kemampuan senyawa antioksidan dalam menangkal radikal bebas. Suatu senyawa dinyatakan sebagai senyawa antioksidan apabila memiliki aktivitas antioksidan. Isoflavon merupakan senyawa aktif dari kelompok senyawa flavonoid yang berkontribusi sebagai senyawa antioksidan karena memiliki kemampuan untuk menghambat radikal bebas. Hasil penelitian aktivitas antioksidan puree edamame dapat dilihat pada Gambar 2.

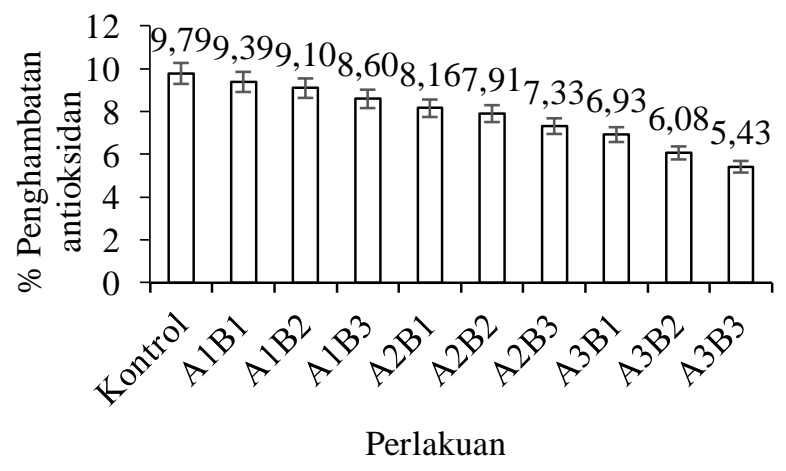

Gambar 2. Aktivitas antiosidan puree edamame dengan variasi tegangan dan waktu PEF
Gambar 2 menunjukkan nilai tertinggi yaitu aktivitas antioksidan kontrol 9,79\% dan terendah pada perlakuan $\mathrm{A}_{3} \mathrm{~B}_{3}$ $5,42 \%$. Penurunan aktivitas antioksidan puree edamame pasca perlakuan $\mathrm{PEF}$, namun masih mampu menghambat radikal bebas pada uji perendaman DPPH. Penurunan ini diakibatkan karena senyawa isoflavon dalam puree edamame terdegradasi oleh adanya tegangan tinggi yang diberikan saat perlakuan PEF.

Hal ini diakibatkan karena antioksidan merupakan senyawa yang mudah rusak akibat pengaruh suhu dan lingkungan sekitarnya. Antioksidan yang berada pada suhu kamar akan mengalami penurunan kualitas yang dikarenakan kondisi lingkungan yang tidak dapat dikendalikan seperti adanya panas dan oksigen sehingga kemungkinan terjadinya oksidasi maupun degradasi antioksidan cukup besar (Sudarmadji et al., 2007).

\section{Warna (Nilai Hue Angle)}

Nilai hue puree edamame mengalami penurunan pasca perlakuan PEF, namun penurunan yang terjadi tidak terlalu signifikan jauh dari nilai standart warna hijau. Hasil penelitian nilai hue puree edamame yang diperoleh dari tanpa atau dengan perlakuan PEF terdapat pada rentan warna hijau kekuningan yang menunujukkan warna dasar bahan yaitu edamame, nilai hue dapat dilihat pada

\section{Gambar 3.}

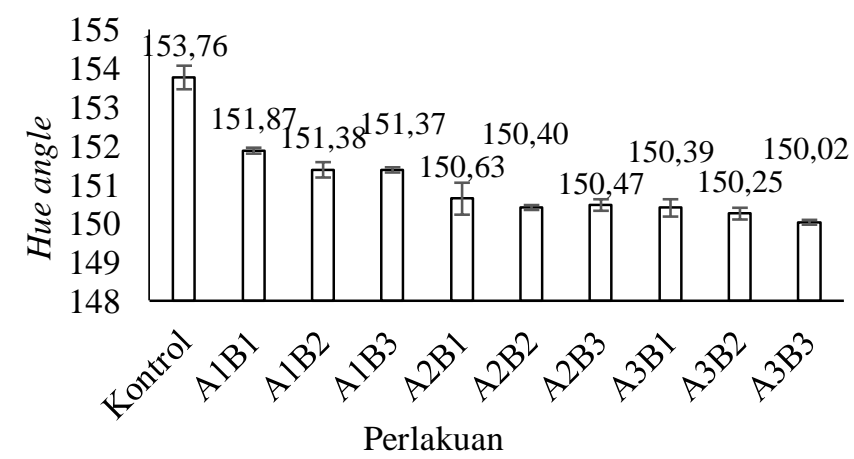

Gambar 3. Nilai hue angle puree edamame dengan variasi tegangan dan waktu PEF 
Gambar 3 menunjukkan hasil pengukuran nilai hue tertinggi terdapat pada puree edamame tanpa PEF $(153,758)$ dan nila ihue terendah terdapat pada perlakuan puree edamame perlakuan PEF tegangan $45 \mathrm{kV}$ selama 30 detik $(150,023)$. Pada penelitian ini, digunakan perlakuan PEF dengan kombinasi variasi tegangan dan waktu yang ditempatkan pada chamber yang dilengkapi dengan katoda dan anoda sehingga puree edamame mngalami kontak langsung dengan alat tersebutsehingga diduga kandungan klorofil dalam edamame mulai terdegrasi, karena klorofil terdapat dalam bentuk ikatan kompleks dengan protein yang menstabilkan molekul klorofil dengan cara memberikan ligan tambahan. Tegangan tinggi yang diberikan mengakibatkan protein terdenaturasi sehingga klorofil menjadi tidak terlindung lagi dan mudah diserang yang berpengaruh terhadap aktivitas klorofilase (Taylor, 1984).

\section{Karakteristik selama Penyimpanan Warna (hue angle)}

Nilai hue angle puree edamame selama penyimpanan dua minggu, dapat dilihat pada Tabel 2. Nilai hue tertinggi terdapat pada puree edamame perlakuan PEF tegangan $35 \mathrm{kV}$ selama 10 detik $(148,995)$ dan nilai hue terendah terdapat pada puree edamame tanpa perlakuan PEF $(148,264)$.

Penurunan ini disebabkan selain klorofil $\mathrm{b}$ atau pigmen hijau yang terdapat pada edamame mengalami degradasi akibat terdenaturasinya protein, pergantian atom magnesium pada molekul klorofil oleh atom hidrogen membentuk feofitin, atau pembentukan klorofilid oleh enzim klorofilase dan oksidasi selama penyimpanan. Hal ini juga diakibatkan karena karotenoid dan xantofil yang semula tertutup menjadi terbuka pada saat penyimpanan dengan adanya suhu dingin, dengan terbukanya dua senyawa tersebut dapat memudarkan pigmen klorofil yang menyebabkan semakin lama warna berubah menjadi kuning kecoklatan akibat pigmen coklat dari ke dua senyawa yang keluar (Clydesdale, 1976).

Tabel 2. Nilai hue angle purre edamame

\begin{tabular}{|c|c|c|c|}
\hline \multirow[b]{2}{*}{ Perlakuan } & \multicolumn{3}{|c|}{ Nilai Hue Angle } \\
\hline & $\begin{array}{c}\text { Minggu } \\
\text { ke -0 }\end{array}$ & $\begin{array}{c}\text { Minggu ke } \\
-1\end{array}$ & $\begin{array}{c}\text { Minggu } \\
\mathrm{ke}-2\end{array}$ \\
\hline Kontrol & 153.758 & 150.444 & 148.264 \\
\hline $\mathrm{A}_{1} \mathrm{~B}_{1}$ & 151.87 & 148.99 & 148.641 \\
\hline $\mathrm{A}_{1} \mathrm{~B}_{2}$ & 151.376 & 148.622 & 148.595 \\
\hline $\mathrm{A}_{1} \mathrm{~B}_{3}$ & 151.374 & 148.598 & 148.542 \\
\hline $\mathrm{A}_{2} \mathrm{~B}_{1}$ & 150.631 & 148.51 & 148.402 \\
\hline $\mathrm{A}_{2} \mathrm{~B}_{2}$ & 150.404 & 148.422 & 148.382 \\
\hline $\mathrm{A}_{2} \mathrm{~B}_{3}$ & 150.468 & 148.444 & 148.37 \\
\hline $\mathrm{A}_{3} \mathrm{~B}_{1}$ & 150.393 & 148.385 & 148.342 \\
\hline $\mathrm{A}_{3} \mathrm{~B}_{2}$ & 150.246 & 148.37 & 148.335 \\
\hline $\mathrm{A}_{3} \mathrm{~B}_{3}$ & 150.023 & 148.321 & 148.305 \\
\hline
\end{tabular}

Keterangan : Kontol tanpa menggunakan perlakuan PEF; $\mathrm{A}_{1} \mathrm{~B}_{1}=35 \mathrm{kV} ; 10$ detik; $\mathrm{A}_{1} \mathrm{~B}_{2}=$ $35 \mathrm{kV} ; 20$ detik; $\mathrm{A}_{1} \mathrm{~B}_{3}=35 \mathrm{kV} ; 30$ detik; $\mathrm{A}_{2} \mathrm{~B}_{1}=40 \mathrm{kV} ; 10$ detik; $\mathrm{A}_{2} \mathrm{~B}_{2}=$ $40 \mathrm{kV} ; 20$ detik; $\mathrm{A}_{2} \mathrm{~B}_{3}=40 \mathrm{kV} ; 30$ detik; $\mathrm{A}_{3} \mathrm{~B}_{1}=45 \mathrm{kV} ; 10$ detik; $\mathrm{A}_{3} \mathrm{~B}_{2}=$ $45 \mathrm{kV} ; 20$ detik; $\mathrm{A}_{1} \mathrm{~B}_{2}=45 \mathrm{kV} ; 30$ detik.

Berdasarkan rumus persamaan linear $\mathrm{y}=1,16 \mathrm{x}+150,39$ diperoleh hasil perkiraan umur simpan puree edamame dikatakan tidak layak berdasrkan warna yaitu pada minggu ke lima. Hal ini dikarenakan pada minggu ke lima warna puree edamame tidak menunjukkan kesegaran warna hijau melainkan warna memudar menjadi kuning kecoklatan berdasarkan dari tabel hue angle.

\section{Total pertumbuhan mikroba}

Hasil total mikroba setelah penyimpanan selama dua minggu dapat dilihat pada Tabel 3. Hasil total mikroba setelah disimpan selama dua minggu pertumbuhan mikroba tertinggi terdapat pada puree edamame tanpa perlakuan PEF $(7,750 \log \mathrm{Cfu} / \mathrm{ml})$ dan pertumbuhan mikroba terendah terdapat pada puree perlakuan PEF tegangan $45 \mathrm{kV}$ selama 30 $\operatorname{detik}(5,195 \log \mathrm{Cfu} / \mathrm{ml})$. 
Peningkatan total mikroba setelah penyimpanan dapat diakibatkan dari spora mikroba yang dibentuk pada saat pengolahan tumbuh membentuk bakteri sel tunggal. Pada dasarnya beberapa bakteri pada kondisi yang tidak menguntungkan dapat memproduksi bentuk pertahanan hidup yang disebut endospora, seperti Bacillus dan Clostridium. Proses ini dikenal sebagai sporulasi, spora bakteri berbeda dengan spora pada jamur, spora bakteri tidak mempunyai fungsi sebagai alat reproduksi. Endospora ini tahan terhadap kondisi lingkungan ekstrim seperti suhu yang tinggi, kekeringan, senyawa kimia beracun (desinfektan, antibiotik) dan radiasi UV. Keadaan ini merupakan fase tidur dari bakteri, endospora mampu bertahan sampai kondisi lingkungan kembali menguntungkan kemudian membentuk proses germinasi dan membentuk bakteri sel tunggal (Sidhar, 2010).

Tabel 3 Pertumbuhan mikroba puree edamame

\begin{tabular}{|c|c|c|c|}
\hline \multirow{2}{*}{ Perlakuan } & \multicolumn{3}{|c|}{$\begin{array}{l}\text { Total Pertumbuhan Mikroba (log } \\
\text { Cfu/ml) }\end{array}$} \\
\hline & $\begin{array}{c}\text { Minggu ke - } \\
0\end{array}$ & $\begin{array}{c}\text { Minggu ke - } \\
1 \\
\end{array}$ & $\begin{array}{c}\text { Minggu } \\
\text { ke }-2 \\
\end{array}$ \\
\hline Kontrol & 3,447 & 7,379 & 7,750 \\
\hline $\mathrm{A}_{1} \mathrm{~B}_{1}$ & 3,094 & 5,892 & 6,751 \\
\hline $\mathrm{A}_{1} \mathrm{~B}_{2}$ & 2,931 & 5,762 & 6,189 \\
\hline $\mathrm{A}_{1} \mathrm{~B}_{3}$ & 2,931 & 5,401 & 5,694 \\
\hline $\mathrm{A}_{2} \mathrm{~B}_{1}$ & 2,849 & 5,505 & 5,688 \\
\hline $\mathrm{A}_{2} \mathrm{~B}_{2}$ & $\begin{array}{l}\text { Tidak } \\
\text { tumbuh } \\
\text { Tidak }\end{array}$ & 5,226 & 5,505 \\
\hline $\mathrm{A}_{2} \mathrm{~B}_{3}$ & tumbuh & 5,075 & 5,489 \\
\hline & Tidak & Tidak & \\
\hline $\mathrm{A}_{3} \mathrm{~B}_{1}$ & $\begin{array}{l}\text { tumbuh } \\
\text { Tidak }\end{array}$ & $\begin{array}{l}\text { tumbuh } \\
\text { Tidak }\end{array}$ & 5,464 \\
\hline $\mathrm{A}_{3} \mathrm{~B}_{2}$ & $\begin{array}{l}\text { tumbuh } \\
\text { Tidak }\end{array}$ & $\begin{array}{l}\text { tumbuh } \\
\text { Tidak }\end{array}$ & 5,401 \\
\hline $\mathrm{A}_{3} \mathrm{~B}_{3}$ & tumbuh & tumbuh & 5,195 \\
\hline Keterangan & $\begin{array}{l}\text { Kontol tanp } \\
\text { PEF; } \mathrm{A}_{1} \mathrm{~B}_{1} \\
35 \mathrm{kV} ; 20 \\
\text { detik; } \mathrm{A}_{2} \mathrm{~B}_{1} \\
40 \mathrm{kV} ; 20 \\
\text { detik; } \mathrm{A}_{3} \mathrm{~B}_{1}\end{array}$ & $\begin{array}{l}\text { menggunakat } \\
35 \mathrm{kV} ; 10 \mathrm{de} \\
\text { etik; } \mathrm{A}_{1} \mathrm{~B}_{3}= \\
40 \mathrm{kV} ; 10 \mathrm{de} \\
\text { etik; } \mathrm{A}_{2} \mathrm{~B}_{3}= \\
45 \mathrm{kV} ; 10 \mathrm{de}\end{array}$ & $\begin{array}{l}\text { oerlakuan } \\
\mathrm{A}_{1} \mathrm{~B}_{2}= \\
\mathrm{kV} ; 30 \\
\mathrm{x} \mathrm{A}_{2} \mathrm{~B}_{2}= \\
\mathrm{kV} ; 30 \\
\mathrm{x} \mathrm{A}_{3} \mathrm{~B}_{2}=\end{array}$ \\
\hline
\end{tabular}

$45 \mathrm{kV} ; 20$ detik; $\mathrm{A}_{1} \mathrm{~B}_{2}=45 \mathrm{kV} ; 30$ detik.

\section{KESIMPULAN}

Perbedaan variasi tegangan dan waktupenggunaan Pulsed Electric Field (PEF) dapat menurunkan aktivitas enzim protease hingga $88,5 \%$, total mikroba 80 $89 \%$, aktivitas antioksidan $44,5 \%$ dan warna $2,43 \%$. Perlakuan tersebut diperkirakan dapat mempetahankan kualitas warna puree edamame hingga lima minggu dua hari berdasarkan rumus persamaan linear dan memperlambat pertumbuhan mikroba selama dua minggu.

\section{UCAPAN TERIMAKASIH}

Penulis mengucapkan banyak terimakasih kepada PT. Indofood Sukses Makmur Tbk. Yang telah memberikan dana peneitian melalui beasiswa progam Indofood Riset Nugraha 2016/2017.

\section{DAFTAR PUSTAKA}

Andriawan, Veri dan Susilo, Bambang. 2015. "Susu Listrik" Alat pasteurisasi susu kejut listrik tegangan tinggi (pulsed electric field) menggunakan transformator tegangan tinggi dan inverter. Jurnal Ketenikan Tropis dan Biosistem, 3 (2) : 199-210.

Broto, W. 2003. Teknologi Penanganan Pasca Panen Buah Untuk Pasar. Agromedia Pustaka, Jakarta.

Barbosa-Cánovas, G., M.M. Gongora-Nieto., U.R. Pothakamury. dan B.G. Swanson. 1999. Preservation Of Foods With Pulsed Electric Fields. Academic Press Ltd, London.

Chandrasekaran, Muthusamy. 2015. Enzymes in Food and Beverage Processing. CRC Press Taylor and Francis Group. Ebook Online. https://books.google.co.jp. [Diakses 5 Januari 2017]. 
Choviya, La dan Ika, Ratna. 2011. Penerapan pulsed electric field pada pasteurisai buah apel varietas ana : Kajian karakteristik nilai gizi, sifat fisik, sifat kimiawi dan mikrobia total. Journal of Agritech, 31 (4).

Clydesdale, F. M., dan F. J. Francis. 1976. Pigments dalam O. R. Fennema. Principles of Food Science. Marcel Dekker Inc, New York.

Cuenca, R.A., Suarez, V., Sevilla, R.M.D., dan Aparicio, M.I. 2006. Chemical compotition and dietary fiber of yellow and green commercial soybeans (glycine max). Journal of Food Chemistry, 101 (2).

Cueva, Olga A. 2003. Pulsed Electric Field Influences On Acid Tolerance, Bile Tolerance, Protease Activity And Growth Characteristics Of Lactobacillus Acidophilus La-K. Escuela Agrícola Panamericana Zamorano, Honduras.

Guderjan, M., Elez, M., and Knorr, D. 2007. Application of pulsed electric fields at oil yield and content of functional food ingredients at the production of rapeseed oil. Innov Food Sci Emerg, 8: 55-62.

Herdyastuti, N. 2006. "Isolasi dan Karakterisasi Ekstrak Kasar Enzim Bromelin dari Batang Nanas (Ananas comosus L. Merr.)". Skripsi. Fakultas MIPA Jurusan Kimia Universitas Surabaya.

Hutching, J.B. 1999. Food Color and Appearance. Aspen publisher Inc, Marylan.

Johnson D., Wang, S., and Suzuki, A. 1999. Edamame vegetable soybean for Colorado. In Janick, J. (Ed.). Perspectives on New Crops and New Uses. Di dalam. Riyanto, C., Maria L., dan Pranata S. 2006. "Kualitas Mie Basah dengan Kombinasi Edamame (Glycine max (L.) merril) dan Bekatul Beras Merah". Skripsi. Fakultas Teknologi Atma Jaya, Jakarta.
Konovsky J., Lumpkin, T.A., dan Mclary D. 1994. Edamame : The vegetable soybean. In O'Rourke, A.D. (Ed.). Di dalam Konovsky, J. 2004. Understanding The Japanese Food and Agrimarket: A Multifaceted Opportunity. Haworth Press, Binghamton

Lee, J.H., Seog, E.J., dan Choi, Y.H. 1998. Color characteristics of soybeans as influenced by freezing and cooking conditions. J. Food Sci. Nutr, 3 (2) : 105-110.

Lenny, S. 2006. "Senyawa Flavonoida, Fenilpropanoida dan Alkaloida". Skripsi. Fakultas MIPA Universitas Sumatra Utara.

Lingga, Lanny, Ph. D., 2012. The Healing Power of Antioxidant: Mengenal Lebih Jauh Sumber Antioksidan Unggulan. Gramedia, Jakarta.

Lopez, N., Puertolas, E., Condon, S.,Alvarez, I., dan Raso, J. 2008. Application of pulsed electric fields for improving the maceration process during vinification of red wine : Influence of grape variety. Eur Food Res Technol, 227: 10991107.

Meilgard, M., Civille, G.V., dan Carr, B.T. 1999. Sensory Evaluation Techniques. CRC Press, New York.

Muslim, C., La, C. Hawa. dan Bambang D. Argo. 2013. Pasteurisasi non-thermal pada susu sapi segar untuk inaktivasi bakteri Staphylococcus aureus berbasis Pulsed Electric Field (PEF). Jurnal Ketenikan Pertanian Tropis dan Biosistem, 1 (1): 35-49.

Molyneux, P. 2004. The use of the stable free radical diphenylpicrylhydrazyl (DPPH) for estimating antioxidant activity songklanakarin. J. Sci. Technol, 26 (2) : 211-219.

Nguyen, V.Q. 2001. Edamame (Vegetable Green Soybean). In The Rural Industrial pege : 49-56. http://attar.ncut.org/attarpub/edamame.html/ [Diakses 1 Maret 2016]. 
Nooman, A. K., Ashok, K. S., Atif, A. O., Zaha, E. A., dan Husni, F. 2008. Antioxidant activity of some common plants. Journal Biology, 32 : $51-55$.

Oh, D.G., Jang, Y.K., Woo, J.E., Kim, J.S., dan Lee, C.H. 2016. Metabolomic is reveals the effect of garlic on antioxidant and protease activities during cheonggukjang (fermented soybean paste) fermentation. Food Research International, 82: 86-94.

Pujiastuti, L. 2015. Kedelai Jepang Made in Jember Rambah Pasar Eropa dan AS. http://finance.detik.com/read/2015/07/2 1/145003/2972179/4/kedelai-jepangmade-in-jember-rambah-pasar-eropadan-as [Diakses 2 Maret 2016].

Pusdatin. 2014. Kedelai Jember Tembus Pasar Internasional.

http://setkab.go.id/kedelai-jembertembus-pasarinternasional/ [Diakses 2 Maret 2016].

Quass, D. W. 1997. Pulsed Electric Field Processing In The Food Industry. A Status Report On Pulsed Electric Field. Palo Alto, CA. Electric Power Research Institute. Page 23-35. CR- 109742.

Rahmadi A. 2009. "Aplikasi Bakteri Asam Laktat untuk Meningkatkan Keamanan Mikrobiologis Terhadap Staphylococcus aureus pada Proses Olah Minimal Buah Apel Malang (Malussylvestris Mill)". Skripsi. Fakultas Pertanian THP Universitas Mulawarman.

Sale, A. J. H., and Hamilton, W. A., 1967. Effect of High Electricfields on Microorganisms. I. Killing of Bacteria and Yeast. Biochim Biophys Acta, 148 : 781-788.

Sridhar. 2010. Anatomy of Bacteria Cell. http://www.microrao.com. [Diakses pada tanggal 01Mei 2017].

Sudarmaji, S., B. Haryono dan Suhardi.2007. Analisa Bahan Makanan dan Pertanian. Liberty, Yogyakarta.
Taylor, A. J. 1984. Natural Colours in Food. In Developments in Food Colours 2. J. Walford (ed.). Elsevier Applied Science Pub. London \& New York. page 193 196.

Titiek, F., Djafar, S. R. Endang, R. Siti. 2009. Cemaran Mikroba pada Susu dan Produk Unggas. Balai Pengkajian Teknologi Pertanian. Fakultas Teknologi Pertanian Universitas Gajah Mada.

Van Heesch. B, G.A.J.M. Pemen, Dan P. Huijbrechts. 2004. A Fast Pulsed Power Source, Applied To Treatment Of Conducting Liquids. IEEE Transaction on Plasma Science.

Winarno, F.G. 2004. Kimia Pangan dan Gizi. Gramedia Pustaka Utama, Jakarta.

Winarti, Sri. 2010. Makanan Fungsional. Graha Ilmu, Yogyakarta.

Wszelaki, A.L., Delwiche, J.F., Walker, S.D., Ligget, R.E., Miller, S.A., dan Kleinhenz, M.D. 2005. Consumer liking and descriptive analysis of six varieties of organically grown edamame- type soybean. Journal Food Quality and Preference, 16 (2).

$\mathrm{Xu}$, Y., Sismour, E., Pao, S., Rutto, L., Grizzard, C., dan Ren, S. 2012. Textural and microbiological qualities of vegetable soybean (edamame) affected by blancing and storage conditions. Jurnal of Food Process Technology, 3 (5).

Yamaguchi T., Takamura H., Matoba T., Terao J. 1998. HPLC method for evaluation of the free radicalscavenging activity of foods by using 1,1,-diphenyl-2-picrylhydrazyl. Biosci. Biotechnol Bioche,. 62 : 1201-1204.

Ziwei, L., Z.Cheng, G.S. Mittal. 2006. Inactivation of spoilage microorganisms in apple cider using a continuous flow pulsed electric field system. Journal of Food Sciences, 39: 350-356. 